16. Scheglov, E. A., Vezikova, N. N. (2012). Osobennosti klinicheskoi kartiny u pacientov osteoartrozom kolennykh sustavov i sochetannym porazheniem ven nizhnikh konechnostei. Sovremennye problemy nauki i obrazovaniia, 1, 65-71.

17. Liubarskii, M. S., Mustafaev, N. R. (2011). Izmeneniia gemolimfocirkuliacii nizhnikh konechnostei pod vliianiem fizioterapevticheskikh metodov v lechenii osteoartroza kolennykh. Sovremennye problemy nauki i obrazovaniia, 1, 23-26.

Received date 05.06.2020

Accepted date 26.06.2020

Published date 31.07.2020

Valeriia Orlenko, PhD, Head of Department, Scientific Advisory Department of Ambulatory and Preventive Care in Patients with Endocrine Disorders, State Institution "V. P. Komisarenko Institute of Endocrinology and Metabolism of the National Academy of Medical Sciences of Ukraine”, Vyshgorodska str., 69, Kyiv, Ukraine, 04114

E-mail: orleva@ukr.net

Kateryna Ivaskiva, $\mathrm{PhD}$, Senior Researcher, Scientific Advisory Department of Ambulatory and Preventive Care in Patients with Endocrine Disorders, State Institution "V. P. Komisarenko Institute of Endocrinology and Metabolism of the National Academy of Medical Sciences of Ukraine”, Vyshgorodska str., 69, Kyiv, Ukraine, 04114 E-mail: k_iva@ukr.net

Galyna Zubkova, PhD, Chief Researcher, Department of Reproductive Endocrinology, State Institution "V. P. Komisarenko Institute of Endocrinology and Metabolism of the National Academy of Medical Sciences of Ukraine", Vyshgorodska str., 69, Kyiv, Ukraine, 04114

E-mail: galina_zubkova@mail.ua

UDC 616.314-77:539.216.2:620.179.1

DOI: 10.15587/2519-4798.2020.209168

\title{
MICROHARDNESS OF FIBERGLASS - REINFORCED PHOTOCOMPOSITE MATERIAL UNDER DIFFERENT CONDITIONS OF LIGHT POLIMERIZATION
}

\section{A. Udod, O. Roman}

Мета: у лабораторних умовах вивчити мікротвердість змічңненого скловолокном фотокомпозита за різних режимів світлової дії у різні терміни.

Матеріали та методи. Мікротвердість зміцненого скловолокном фотокомпозита еverX Posterior, GC, досліджували на 60 зразках за допомогою мікротвердометра ПМТ-3 у термін 1 година, 1 та 7 діб після полімеризації. Зразки ичліндричної форми висотою 3 мм 1 групи опромінювали світловим потоком фотополімеризатора за «м'яким стартом», зразки 2 групи полімеризували світлом потоком з постійною високою інтенсивністю $1400 \mathrm{MBm} / \mathrm{cm}^{2}$.

Результати дослідження. Через 1 годину мікротвердість на найближчій до світловода поверхні дорів-

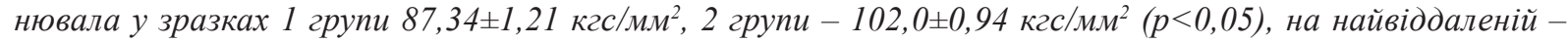

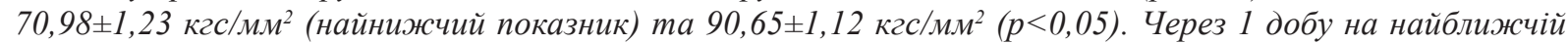

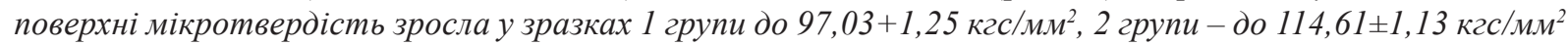

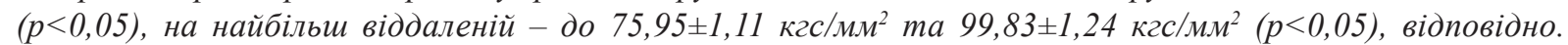

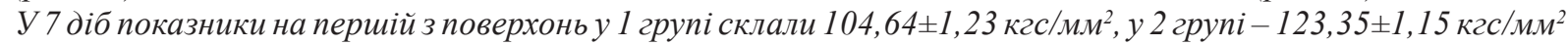

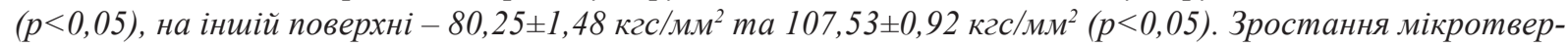
дості на ицих поверхнях за увесь термін склало у зразках 1 групи 16,5\% та 11,6 \%, 2 групи - 17,3\% ma $15,7 \%$.

Висновки. Світловий потік постійної високої інтенсивності забезпечує статистично значущзе (p<0,05) більш високі показники мікротвердості зміцненого скловолокном фотокомпозита на усіх поверхнях зразків, ніж світловий вплив за «м'яким стартом». Під час прямого відновлення зубів необхідно зменшувати товщину шару фотокомпозита у разі полімеризащії за «м'яким стартом»

Ключові слова: змічнений скловолокном фотокомпозит, мікротвердість, полімеризація, світловий потік, інтенсивність, «м'який старт» 


\section{Introduction}

Dental restoration technologies, which have made it possible to restore the anatomical shape and aesthetic properties of carious teeth, are constantly being improved and optimized. The arsenal of restorative materials, among which the most popular are photocomposites, is constantly expanding, new materials appear, which are more adapted to certain clinical requirements and their properties are close to the corresponding, typical for hard tissues of natural teeth. Most photocomposite materials used in clinical practice are universal, i. e. they can be used for direct restoration of teeth of all groups with carious and non-carious lesions of different localization and volume [1]. However, photocomposites are also used for differentiated use, for example, for the restoration of frontal or lateral teeth.

Recently, photocomposite materials have been offered for implementation, which have a rather limited application, but at the same time have a number of important improved properties. These include fluid materials, the use of which allows due to their properties in some way to neutralize the negative effects of polymerization stress during curing of photocomposites, which cover the layer of fluid material during tooth restoration [2]. However, among the fluid photocomposites there are already strengthened, which can be used independently for direct restoration of teeth with carious cavities with a depth of not more than $4 \mathrm{~mm}$, as well as in other areas of teeth in the absence of high mechanical load [3].

Glass-fiber reinforced materials are also limited use photocomposites. These photocomposites contain in their structure short, cross-linked fibers, the presence of which in the materials significantly increases their mechanical strength and at the same time resistance to cracking [4]. The fiberglass in the material forms a mesh that strengthens it and counteracts the appearance of cracks. This photocomposite replaces dentin, i. e. it can be used with a layer thickness of $4 \mathrm{~mm}$ only in a closed "sandwich technique" with mandatory coating with a traditional photocomposite, and the thickness of the latter layer should not be less than a certain value [5].

The risk of cracks in direct photocomposite restorations is especially significant in large cavities located in the lateral teeth, with no vertical walls or after endodontic treatment. It is in such cases that the use of fiberglass-reinforced photocomposite is shown, but it is necessary to ensure its full hardening and the acquisition of certain strength characteristics, which depend on the duration of the recovery.

Recommendations on light exposure for the polymerization of fiberglass-reinforced photocomposite contain information on the light source, luminous flux intensity and duration of irradiation $[6,7]$. At the same time, there is no information regarding the mode of light exposure (constant high intensity or "soft start" with a gradual or sharp increase in intensity). However, it is well known that the specific light energy significantly affects the achievement of any photocomposite material a certain level of hardening, moreover, hardening continues for some time after light exposure, stretching for several days [8]. During this time, the physical and mechanical characteristics of the photocomposite improve, in particular, the microhardness, the indicators of which can give an idea of the degree of polymerization of the material. In this regard, it is advisable to study the microhardness of the photocomposite material, reinforced with fiberglass, which hardens under light exposure in different modes, with tracking of its parameters over time.

The aim of the study - in laboratory conditions to determine the mode of light polymerization, which contributes to the achievement of high microhardness of fiberglass-reinforced photocomposite material at different times.

\section{Materials and methods}

Laboratory study of microhardness of fiberglass-reinforced photocomposite for dentin replacement everX Posterior, GC, was conducted at the Department of Dentistry No. 1 of Donetsk National Medical University in 2018-2019. Microhardness was studied on 60 samples, which were divided into two groups of 30 samples each, depending on the mode of light exposure during polymerization of the material. Samples of group 1 were irradiated with light flux of LED photopolymer in the "soft start" mode with a final intensity of $1400 \mathrm{~mW} / \mathrm{cm}^{2}$, samples of material of group 2 were exposed to light flux of the same photopolymer with a constant high intensity of $1400 \mathrm{~mW} / \mathrm{cm}^{2}$.

Samples of fiberglass-reinforced photocomposite for the study of microhardness were made using a special detachable mold [8]. The test material was filled into the specified form, then in different modes, according to the division into groups, it was irradiated with a light flux of LED photopolymerizer, placing the LED at a minimum distance from the surface of the samples, then grinding and polishing to shine. Samples of material prepared for the study had the form of cylinders with a height of $3 \mathrm{~mm}$ and a diameter of $4 \mathrm{~mm}$. This height was due to the results of a previous study of the depth of polymerization of this material, according to which the influence of light flux of any photopolymerizer in the "soft start" does not allow to obtain the recommended parameter of $4 \mathrm{~mm}$ [9].

Hardness was performed first on the surface of the samples, on the side of which was the light of the photopolymerizer during irradiation, it was designated as the surface A.

Then the samples were ground $2 \mathrm{~mm}$ from the specified surface, polished a new slice with the designation of it as surface B, and again measured the microhardness. The study was completed by measuring the microhardness on the surface that was furthest from the fiber (surface C). Microhardness was determined at five points on each surface. Samples of fiberglass-reinforced photocomposite were examined several times after light polymerization of the material, in particular after 1 hour, 1 day and 7 days.

To study the studied physical parameter, a PMT-3 microhardness tester was used, which includes a microscope with a slide table and a diamond pyramid with a load mechanism. A sample of the photocomposite for the 
study was fixed on a slide, then, setting a load of $100 \mathrm{~g}$, slowly lowered the diamond pyramid, brought it to the surface of the sample, immersed in the material for 5 seconds and obtained an impression. Next, the impression was examined with a microscope and the length of its diagonal in $\mathrm{mm}$ was determined using an eyepiece-micrometer measuring drum.

Indicators of microhardness $\mathrm{H}$ (in $\mathrm{kgf} / \mathrm{mm}^{2}$ ) were determined by considering it as a fraction of the load distribution $\mathrm{P}$ (in $\mathrm{kgf}$ ) on the surface of the imprint $\mathrm{C}$ (in $\mathrm{mm}^{2}$ ), provided that the angles of the imprint correspond to those of the diamond pyramid, according to the following formula (1):

$$
\mathrm{H}=1854 \mathrm{P} / \mathrm{C} 2 \text {, }
$$

where $\mathrm{H}$ - microhardness index; $\mathrm{P}$ - loading; $\mathrm{C}$ - diagonal imprint.

Microhardness was studied in accordance with GOST 9450-76 [10].

Statistical processing of the obtained results was performed using variation statistics and Microsoft Excel computer program, microhardness values were given as the mean value and standard error $(\mathrm{M} \pm \mathrm{m})$. Statistically significant differences between the indicators were established using Student's t-test in the presence of $\mathrm{p}<0.05$.

\section{Results}

During the study of the microhardness of the samples of fiberglass-reinforced photocomposite of group 1, it was found that on the surface A 1 hour after light exposure in the "soft start" mode, its value was $87.34 \pm 1.21 \mathrm{kgf} / \mathrm{mm}^{2}$. On surfaces B and C the indicators were statistically significantly $(\mathrm{p}<0.05)$ lower, they were, respectively, $81.05 \pm$ $\pm 1.27 \mathrm{kgf} / \mathrm{mm}^{2}$ and $70.98 \pm 1.23 \mathrm{kgf} / \mathrm{mm}^{2}$ (among themselves these values also differ statistically significantly, $\mathrm{p}<0.05$ ). The same trend was identified in samples of group 2. The highest was the microhardness on the surface A, which was in close proximity to the light source, this figure was $102.0 \pm 0.94 \mathrm{kgf} / \mathrm{mm}^{2}$. From it, as, by the way, and from each other, statistically significant $(\mathrm{p}<0.05)$ differed corresponding indicators of surfaces $\mathrm{B}$ and $\mathrm{C}$ $98.29 \pm 0.88 \mathrm{kgf} / \mathrm{mm}^{2}$ and $90.65 \pm 1.12 \mathrm{kgf} / \mathrm{mm}^{2}$.

During the day, the microhardness of the material on the surfaces A of the samples of both groups increased statistically significantly $(\mathrm{p}<0.05)$, respectively, by $10.0 \%$ and $11.0 \%$, amounting to $97.03 \pm 1.25 \mathrm{kgf} / \mathrm{mm}^{2}$ and $114.61 \pm$ $\pm 1.13 \mathrm{kgf} / \mathrm{mm}^{2}$. At a depth of $2 \mathrm{~mm}$ (surface B), the indicator of samples of group 1 increased $(p<0.05)$ compared with the previous term by $7.1 \%$ to $87.22 \pm 1.18 \mathrm{kgf} / \mathrm{mm}^{2}$, in samples of group 2 growth $(\mathrm{p}<0.05)$ was stable by $11.1 \%$ - up to $109.29 \pm 1.07 \mathrm{kgf} / \mathrm{mm}^{2}$. The dynamics of microhardness on the most distant surfaces (surface C) of samples 1 and 2 groups again showed a more significant relative to the initial values on these surfaces increase in samples of groups 2, the microhardness of the material of these samples increased $(\mathrm{p}<0.05)$ by $9.2 \%$ and was equal to $99.83 \pm 1.24 \mathrm{kgf} / \mathrm{mm}^{2}$, while the microhardness of the samples of photocomposite group 1 increased by $6.5 \%$ to $75.95 \pm 1.11 \mathrm{kgf} / \mathrm{mm}^{2}$.
The next measurement of microhardness was performed 7 days after light polymerization of the photocomposite material. Assessing the dynamics of microhardness on the surfaces closest to the fiber, we note that the growth of indicators when comparing them with those of the previous period was equivalent to samples 1 and 2 groups, the indicators increased $(\mathrm{p}<0.05)$, respectively, by $7.3 \%$ and $7,1 \%$ and amounted to $104.64 \pm$ $\pm 1.2 \mathrm{kgf} / \mathrm{mm}^{2}$ and $123.35 \pm 1.15 \mathrm{kgf} / \mathrm{mm}^{2}$. The values of microhardness on the surfaces B of the samples of both groups were almost at the same level of increase compared to the indicators obtained in the study period of 1 day, they were equal, according to the numbering of groups, $93.18 \pm 1.17 \mathrm{kgf} / \mathrm{mm}^{2}$ and $117.30 \pm 1.24 \mathrm{kgf} / \mathrm{mm}^{2}$, i. e. increased by $6.4 \%$ and $6.8 \%$, but were statistically significantly $(\mathrm{p}<0.05)$ lower than the corresponding values determined on surfaces A. And, finally, on surfaces $\mathrm{C}$ microhardness samples 1 and 2 groups grew slightly differently. If in samples 1 of group microhardness on this surface was determined at the level of $80.25 \pm$ $\pm 1.48 \mathrm{kgf} / \mathrm{mm}^{2}$, which indicates an increase of $5.4 \%$ over time from the previous study, then in samples 2 of group dynamics for this period was more significant, the growth of the indicator almost did not differ from that on other surfaces $-7.2 \%$, microhardness reached $107.53 \pm$ $\pm 0.92 \mathrm{kgf} / 2$, while both indicators were statistically significant $(\mathrm{p}<0.05)$ lower than those indicators on other surfaces of samples.

\section{Discussion}

Thus, during the entire observation period, the microhardness of the fiberglass-reinforced photocomposite material on all surfaces of the studied samples gradually increased, but the dynamics of indicators relative to different groups was unequal. On surfaces A, which were closest to the light source, in samples of group 1 microhardness within 7 days increased by $16.5 \%$ compared to baseline, i. e. that which was determined 1 hour after light exposure, in samples of group 2 the indicator increased at $17.3 \%$. At a depth of $2 \mathrm{~mm}$, ie on surfaces $\mathrm{B}$, the corresponding values of microhardness growth were $13.0 \%$ and $16.1 \%$, and on the most distant surfaces of the samples (surface C) an even greater difference was recorded between the growth rates of 1 and 2 groups, which were, respectively, $11.6 \%$ and $15.7 \%$.

If we compare the microhardness of the studied photocomposite material on the same surfaces of samples of different groups, it becomes obvious that in all terms of the study the microhardness of samples of group 2 is statistically significant $(\mathrm{p}<0.05)$ to exceed the corresponding surface indicators of samples of group 1. The smallest difference between the indicators of the samples of different groups was recorded by comparing the microhardness on the surfaces closest to the light source A, and it increased over time. The microhardness on the B surfaces of the samples of both groups differed significantly, but the difference between the indicators reached the greatest value in the study of the most distant surfaces of the samples of 1 and 2 groups, especially within 7 days. 
The proximity of the surfaces A of the samples to the light source in some way in the first period of the study eliminates the influence of different modes of light flux, but on the most distant surfaces, the loss of light flux, which inevitably occurs when passing through a sample height of $3 \mathrm{~mm}$ polymerization of the material, the degree of which can be assessed by microhardness [11].

It is to increase over time the intensity of light flux from minimum at the beginning to the final maximum, is inferior to the influence of light flux of constant high intensity to provide the entire sample composite sufficient light energy. But, on the other hand, the continuation of the pregel phase of curing of photocomposite materials, which is achieved by applying irradiation on a "soft start", helps to reduce the negative effects of polymerization stress in the form of significant shrinkage that occurs in photocomposites during light exposure and leads to a number of clinical complications, in particular, such as postoperative sensitivity of hard tissues of restored teeth, violation of the marginal fit of materials, secondary caries, etc. [12]. At the same time, incomplete curing of photocomposites, monomer residue, insufficient mechanical strength can also be the cause of numerous complications.

Given that fiberglass-reinforced photocomposite is recommended for use as a base in a closed "sandwich technique", and it performs an important supporting function in the design of direct restoration, it may be necessary to be careful with the recommendations to use it in large carious cavities and in teeth after endodontic treatment with one layer $4 \mathrm{~mm}$ thick and without clarification regarding the mode of light exposure [13]. It should also be borne in mind that the fiberglass-reinforced photocomposite must be closed with a traditional photocomposite, which must also be irradiated with light flux, i. e. the base of the reduction will receive additional light energy.

Study limitations. The study did not include samples of photocomposite material that did not meet the size requirements, had damage, chips, cracks, filling defects that occurred during manufacture, as well as if the samples were partially or completely destroyed during the study or the surface of the samples were contaminated without the possibility of cleaning them, avoiding additional damage.

Prospects for further research. In the future it is planned to continue laboratory studies of physical and mechanical properties of fiberglass-reinforced photocomposite material in terms of its curing under different modes of light exposure to determine the optimal requirements for light polymerization and clinical studies on the effectiveness of direct tooth restoration using fiberglass-reinforced photocomposite in different clinical situations.

\section{Conclusions}

The luminous flux of a constant high-intensity LED photopolymer systematically provides statistically significant $(p<0.05)$ higher microhardness values of fiberglass-reinforced photocomposite material on all surfaces of the tested samples than the light effect in the "soft start" mode.

Statistically significant $(\mathrm{p}<0.05)$ the lowest indicators of microhardness in all terms are defined on the most remote surfaces of samples of the investigated photocomposite in case of its hardening under the influence of a light stream in the "soft start" mode, during the whole study, the microhardness on these surfaces increased by $11.6 \%$, while under the influence of light of constant high intensity - by $15.7 \%$.

The results of the study of the microhardness of the fiberglass-reinforced photocomposite indicate the need to reduce the thickness of the layer of material under a single application and light polymerization in the "soft start" mode to ensure its full hardening during direct tooth restoration.

\section{Conflict of interest}

The authors declare that they have no conflicts of interest.

\section{References}

1. Borisenko, A. V., Nespryad'ko, V. P., Borisenko, D. A. (2015). Kompozitsionnye plombirovochnye i oblitsovochnye materialy. Kyiv: VSI «Meditsina», 320.

2. Adalaev, H. I. (2017). Zhidkotekuchie kompozitsionnye materialy svetovogo otverzhdeniya. Bulletin of Medical Internet Conferences, 7 (10), 1554-1555.

3. Gryuttsner, A. (2011). Tekuchiy kompozit SDR - umniy zamenitel' dentina. DentArt, 2, 45-52.

4. Wolff, D., Geiger, S., Ding, P., Staehle, H. J., Frese, C. (2012). Analysis of the interdiffusion of resin monomers into prepolymerized fiber-reinforced composites. Dental Materials, 28 (5), 541-547. doi: https://doi.org/10.1016/j.dental.2011.12.001

5. Miletich, I. (2018). Sovremennye resheniya dlya pryamyh restavratsiy zubov distal'noy gruppy. Glavniy vrach Yuga Rossii, $61,6-9$.

6. Garoushi, S., Vallittu, P. K., Watts, D. C., Lassila, L. V. J. (2008). Effect of nanofiller fractions and temperature on polymerization shrinkage on glass fiber reinforced filling material. Dental Materials, 24 (5), 606-610. doi: https://doi.org/10.1016/j.dental.2007.06.020

7. EverX Posterior. Kompozyt dlia zamishchennia dentynu, pidsylenyi voloknom. Available at: https://kristar.ua/upload/iblock/ c18/c185a519bff1c413136026feb1f1913d.pdf

8. Udod, O. A., Bekuzarova, K. I. (2018). Study of nanophotocomposite material microhardness under various hardening conditions. Bulletin of Problems Biology and Medicine, 4.3 (141), 260. doi: https://doi.org/10.29254/2077-4214-2017-4-3-141-260-263 
9. Udod, O. A., Roman, O. B. (2020). Doslidzhennia hlybyny polimeryzatsiyi fotokompozytsiynykh materialiv. Mater. mizhnar. nauk.-prakt. konf. «Medychna nauka ta praktyka na suchasnomu istorychnomu etapi». Kyiv, 116-118.

10. GOST 9450-76. Izmerenie mikrotverdosti vdavlivaniem almaznyh nakonechnikov (1993). Moscow: Izd-vo standartov, 35 .

11. Udod, O. A., Bakuzarova, H. I. (2018). Investigating the Intensity Dynamics of the Photopolymerizer Light Flux in Restorative Materials. Ukrainskyi zhurnal medytsyny, biolohiyi ta sportu, 3 (2), 171-174. doi: https://doi.org/10.26693/ jmbs03.02.171

12. Maniuh, H. Yu., Maksymiv, O. O., Rozhko, V. I. (2012). A modern view of photocomposite filling materials and their features in case of restoring defects of the crown part of the teeth. Bukovynskyi medychnyi visnyk, 16 (1 (61)), 166-170.

13. Garoushi, S., Tanner, J., Vallittu, P., Lassila, L. (2012). Preliminary Clinical Evaluation of Short Fiber-Reinforced Composite Resin in Posterior Teeth: 12-Months Report. The Open Dentistry Journal, 6 (1), 41-45. doi: https://doi.org/10.2174/ 1874210601206010041

Received date 26.05.2020

Accepted date 19.06.2020

Published date 31.07.2020

Oleksandr Udod, MD, Professor, Departament of Dentistry No. 1, Donetsk National Medical University, Pryvokzalna str., 27, Liman, Donetsk region, Ukraine, 84404

E-mail: stomatdecan@dsmu.edu.ua

Oleh Roman, Postgraduate Student, Departament of Dentistry No. 1, Donetsk National Medical University, Pryvokzalna str., 27, Liman, Donetsk region, Ukraine, 84404

E-mail: olko_r@ukr.net 